\title{
New learning environments
}

\section{The importance of information literacy in academia}

\author{
by Hannelore B. Rader
}

\section{LOEX: New Learning Environments}

$\mathrm{E}$ d. Note: This article contains reports on two conferences-the LOEX Conference and the 27 th Workshop on Instruction in $\mathrm{Li}$ braries.

More than 200 persons attended the 28th LOEX Conference, sponsored by Eastern Michigan University (EMU) in Ypsilanti, Michigan, from June 4-6, 1998. The theme of the conference, "New Learning Environments," echoed a number of themes related to the changing learning and teaching situations in academia addressed recently in national, regional, and state library conferences.

The theme was especially appropriate to this conference, held at EMU because it coincided with the opening of Halle Library, a marvelous model of the new electronic library/learning center for the millennium. This facility demonstrates remarkably well how the past meets the future in a completely networked electronic information environment, featuring a unique materials storage component. Two keynote speakers addressed the learning environment. Seven poster sessions provided hands-on information and practical examples of teaching information skills in a variety of settings.

\section{Creating a learning environment}

In "Anatomy of a cybrary for 2003: It's the learning environment, not the wiring," Morell Boone, of EMU, discussed the use of Halle Library in teaching and learning. He outlined the facility's unique electronic and physical features and how they are intended to support and facilitate student learning. Especially important in the new facility will be the enhanced centralized approach to customer services, group learning, and problem-solving.

\section{A history of teaching}

In "The learning environment-then, now, and later: 30 years of teaching information skills," I described the history, development, and progress of library orientation, bibliographic instruction, and information literacy from the beginning of LOEX in 1971 to the present. I discussed the learning environment in terms of teaching information skills throughout the 30-year period, as well as international, national, and local developments related to this topic in terms of publications, associations, conferences, and classroom instruction.

\section{A sampling of programs}

Seventeen presentations by librarians from academic institutions throughout the United States featured information on a variety of information literacy programs and related topics on:

- changes in the attitudes and behaviors of students and their effect on library instruction and providing new instructional opportunities;

- effective teaching methodology for six conceptual areas of electronic research using sample lesson plans in different instructional settings;

\section{About the author}

Hannelor B. Rader is university librarian at the University of Louisville, e-mail: hbrade01@gwise.louisville.edu 
- experiences creating flexible teaching spaces to meet the needs of electronic and distributed learning environments;

- handling requests for electronic classroom use, related plans, and policies;

- integrating a new student-centered electronic teaching classroom, information concourse, and multimedia laboratory;

- a tutoring program for faculty in their offices;

- explanation of basic elements of knowledge mapping and how it can be used in a lecture and in a cooperative learning environment;
- faculty-librarian collaboration at a library arts college, its history, development, and future prospects;

- Web-based tutorials to teach research skills;

- a self-paced interactive computer tutorial for the online catalog; and

- factors that contribute to successful instruction programs at small liberal arts colleges.

Interactions between this large group of instruction librarians indicated the increasing importance of information literacy programs in academic settings and new opportunities for integrating them into the curriculum.

\section{Libraries at the heart of learning}

$\mathrm{M}$ ore than 100 participants attended the 27th Workshop on Instruction in Library Use, sponsored by Queen's University Libraries in Kingston, Canada, May, 20-22, 1998. The theme, "Libraries at the Heart of Learning," addressed the transformation of research libraries into learning organizations and the evolving teaching role of academic librarians. Two keynote speakers and 34 presenters addressed how to prepare for the new learning environments; how to form effective partnerships with teaching faculty; techniques for offering and evaluating new forms of courseintegrated instruction; research on what faculty and students need from librarian/teachers; and models for librarians to become leaders in the learning enterprise. Also featured were 12 poster sessions. The workshop was conducted both in English and French.

\section{NILI: A time for change}

Cerise Oberman, dean of library and information services (SUNY at Plattsburgh), discussed the proposal for the establishment of a National Information Literacy Institute (NILI) to help librarians prepare for their increasingly more significant instruction and education role in higher education. The evolving new learning library model will require new developments in the preparation of librarians in cooperation with academic administrators and teaching faculty. The proposed institute will play a critical role in higher education in terms of recognizing the critical role information literacy will play within the curricula on all educational levels.
In "P is for partnerships: Building a faculty liaison at the University of Louisville," I discussed the energetic outreach efforts on the part of the library faculty at the University of Louisville to integrate the libraries and information literacy fully into the academic enterprise in order to achieve a dynamic learning environment by the 21 st century.

Librarians are working with faculty to integrate electronic information into the teaching and research environment; they are helping faculty rethink the way they teach with technology to achieve resourcebased learning; and they are working toward preparing students for lifelong learning, ensuring that they acquire information skills.

Presenters from 14 academic institutions throughout Canada and one U.S. institution gave presentations on such diverse topics as: compulsory library instruction in a commerce curriculum; self-directed library instruction; Web library instruction, presentation skills; faculty perceptions and attitudes regarding information skills; librarian/faculty partnerships; effective strategies for teaching undergraduates information skills in a large university; and use of an Internet workbook in a health sciences library.

Discussions and interactions among the participants conveyed that the academic environment is in a changing mode and many opportunities exist now for librarians to work with faculty to integrate information skills into various curricula. 


\section{WHY DO 12,000 LIBRARIES IN 56 COUNTRIES USE THE OCLC FIRSTSEARCH SERVICE?}

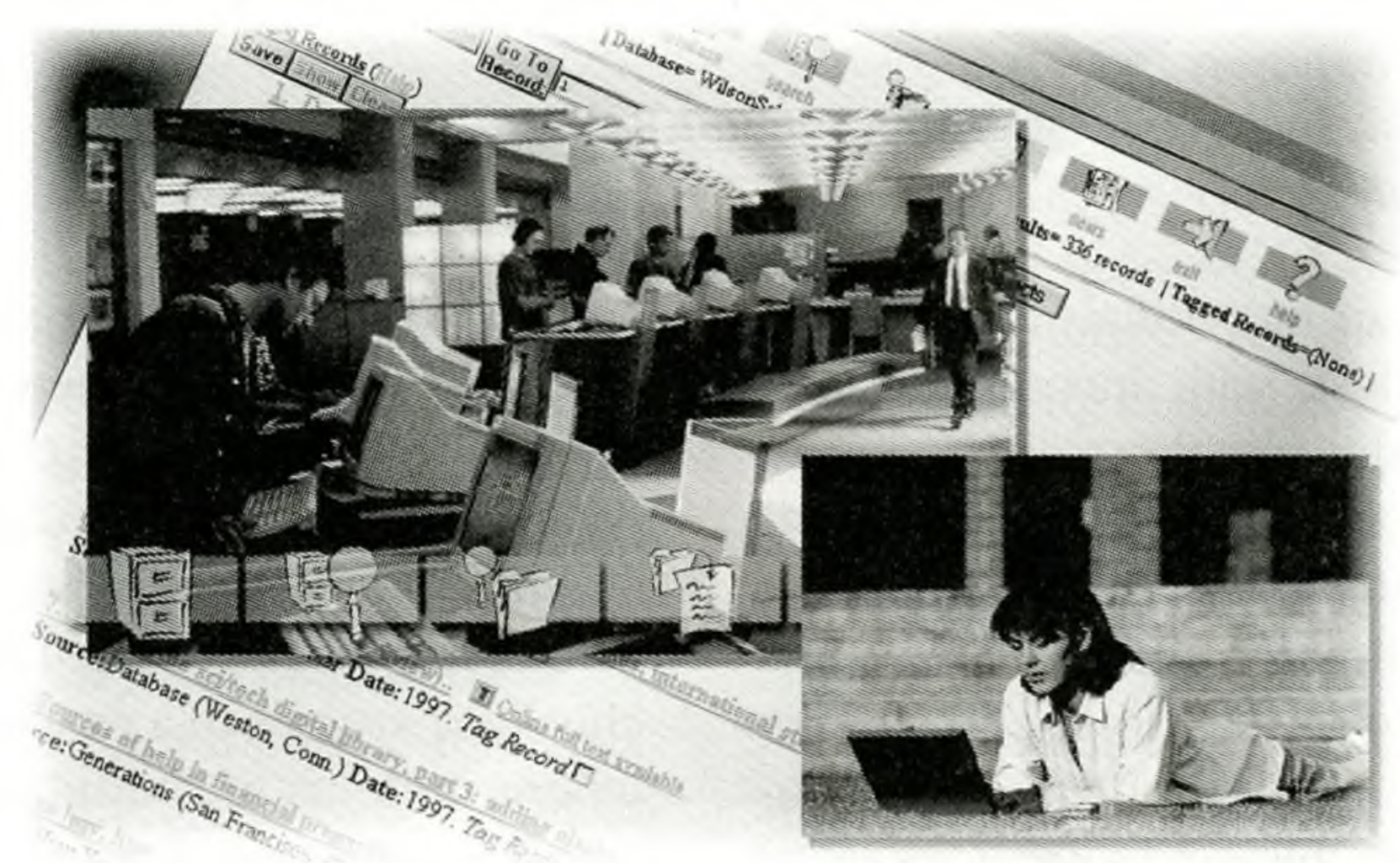

\section{COMPREHENSIVENESS}

- OCLC WORLdCAT, the most consulted database in higher education

- New York Times, the most recent 90 days of articles with abstracts since 1994

- oclC FirstSearch Electronic Collections ONLINE SERVICE, a critical mass of scholarly journal articles

- OClC NetFirst database, unparalleled subject access to Internet resources

- Over 60 other databases covering humanities, science, social studies, and more

\section{FleXibILITY}

- Seamless integration with your collection, LAN, Web services, ILL, online full text, and document delivery
- Mix and match databases, full text, access level, and payment plans to best serve the needs of your users

- Choice of TTY, Web or Z39.50 interface options

- Affordable pricing options: per-search or subscription, individual or group

\section{FULL-TEXT}

- More than one million newspaper and journal articles for immediate online viewing or e-mail delivery

- Electronic reference files: encyclopedias, almanacs, phone books, directories, and financial reports

- Patron-generated full-text document delivery via interlibrary loan, fax, and mail

www.oclc.org

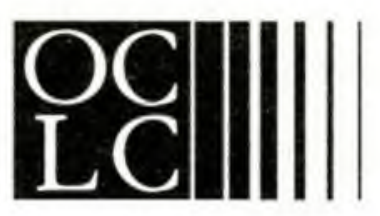

Furthering ACCESS TO THE WORLD's Information 